\title{
Wild and farmed burbot Lota lota: differences in energy consumption and behavior during the spawning season
}

\author{
Ondřej Slavík* , Pavel Horký \\ Department of Zoology and Fisheries, Faculty of Agrobiology, Food and Natural Resources, \\ Czech University of Life Sciences, Prague, Kamýcká 129, 16500 Prague 6, Czech Republic
}

\begin{abstract}
Farmed fish released in a native environment can display different spawning behaviour compared to their wild conspecifics. In our study, farmed and wild burbot, a species recently introduced for aquacultural production, were equipped with electromyogram (EMG) radio tags. EMG biotelemetry allows a description of the spatial distribution of fish together with simultaneous measurements of individual energy consumption. Farmed burbot were released into the wild to simulate stocking or hatchery escape and were observed over a nocturnal phase during November to January. The observational period was assumed to cover the whole spawning season, including an expected peak of spawning activity determined according to egg production by naturally spawning burbot in an experimental seminatural river channel. We detected increased energy consumption and lower movement activity at the time of expected peak spawning for wild burbot only. Across the whole spawning season, farmed females showed lower movement activity and energy consumption than wild females, whereas the opposite results were found for farmed males. Farmed and wild fish kept larger distances between each other than the individuals within a group (farmed and wild) across the whole spawning season. The closest positions occurred between males and females in the wild group, while for farmed fish, the closest position was found within the same sex. Sexually conditioned energy consumption and spatial distribution differed between wild and farmed fish.
\end{abstract}

KEY WORDS: Radio telemetry · Electromyogram - Spawning - Escape simulation · Hatchery experience

\section{INTRODUCTION}

Stocking farmed fish to strengthen waning wild populations and escapes of fish from aquaculture may differentially influence wild populations worldwide (Jensen et al. 2010, Lorenzen et al. 2012, Diserud et al. 2019). Farmed fish can affect the vitality of wild populations (Araki et al. 2007, Buhle et al. 2009, Araki \& Schmid 2010, Lorenzen et al. 2012), especially via kin crossbreeding, leading to losses in genetic diversity (Skaala et al. 2005, Hindar et al. 2006) and morphological differences (Fleming et al. 1994, Kihslinger \& Newitt 2006). Hatchery-reared

\footnotetext{
${ }^{*}$ Corresponding author: oslavik@af.czu.cz
}

fish are stocked under simplified conditions (Einum \& Fleming 2001, Huntingford 2004, Johnsson et al. 2014) at densities too high for natural behaviors to develop (Brockmark \& Johnsson 2010). Hence, after restocking or escape, fish may display changes in behavior and ecology that result in lower survival and vitality in the wild (McGinnity et al. 2003, Jonsson \& Jonsson 2006, Johnsson et al. 2014). In contrast, many successful restoration programs have been reported for rivers affected by overfishing and/or dam construction accompanied by changes in temperature and flow regimes (Stapanian et al. 2006, Harrison et al. 2016a), where weakened wild popula-

(C) The authors 2021. Open Access under Creative Commons by Attribution Licence. Use, distribution and reproduction are unrestricted. Authors and original publication must be credited. 
tions recovered by stocking hatchery-reared fish and restoring habitat (Stapanian et al. 2010, Neufeld et al. 2011, Hardy \& Paragamian 2013, Hardy et al. 2015).

Examples of ongoing discussions about the interactions between wild and farmed fish during spawning include salmonids and codfish. When migrating from the sea to spawning sites in rivers, farmed salmon showed lower homing accuracy than wild salmon (Quinn 1993, Jonsson et al. 2003, Jonsson \& Jonsson 2017). Furthermore, farmed salmon displayed differences in the timing of the spawning season compared to wild salmon, for example, staying longer at sea (Heggberget et al. 1993, Fleming et al. 1997, Aarestrup et al. 2000) and spawning later (Fleming \& Gross 1993) and/or earlier (Lura \& Saegrov 1993, McLean et al. 2003). Moreover, they can show suboptimal energy consumption during spawning migrations, for example, undertaking longer upstream migrations than their wild conspecifics (Thorstad et al. 1998, Moe et al. 2016). In spawning areas, farmed salmon spend less time (Jonsson et al. 1990, Økland et al. 1995), display higher movement activity and occupy less beneficial spawning positions (Berejikian et al. 2001). These characteristics can be associated with the lower ability of farmed fish compared to wild fish to effectively form social hierarchies (Fleming 1996, Weir et al. 2004), agreeing with the finding that spawned farmed fish are subordinate to wild conspecifics (Fleming \& Gross 1993, Fleming et al. 1997, Fleming \& Petersson 2001).

Atlantic cod Gadus morhua (Linnaeus, 1758) display lek-like mating aggregations (Meager et al. 2010) and spawning site fidelity (Skjæraasen et al. 2011) during reproduction, and wild and farmed fish have been observed together at spawning sites (Uglem et al. 2008, Meager et al. 2010, Zimmermann et al. 2013). However, occurrence at the spawning sites differed according to sex. Specifically, aggregation of farmed males rarely occurred at the spawning sites, and these males did not participate in the spawning process, whereas farmed females did, suggesting hybridization between wild and farmed individuals (Meager et al. 2010). Reproductive success, however, is likely not guaranteed by the presence of individuals in mating aggregations alone (Wringe et al. 2015) but also associated with energetically demanding male reproductive behaviors, which are decisive for success in female mate choice (Skjæraasen et al. 2010a). Skjæraasen et al. (2010b) found that wild males fertilized more eggs from wild females than from farmed females, and wild females preferred wild males according to behavioral indicators, whereas farmed males were more frequently rejected. In summary, the behavior of farmed fish during reproduc- tion is species-specific and may differ from that of wild individuals in terms of timing, spatial distribution, movement activity and social interactions.

The burbot Lota lota (Linnaeus, 1758) has recently been extensively studied in the wild (Cott et al. 2013, Harrison et al. 2015, Blábolil et al. 2018) and in aquaculture (Trabelsi et al. 2011, Wocher et al. 2011, Kucharczyk et al. 2018). Yet, information about potential behavioral differences between farmed fish and their wild conspecifics is generally lacking. The burbot, the only freshwater representative of the Gadidae family, is a predator with a northern circumpolar distribution occupying rivers and lakes (Lehtonen 1998). Its occurrence closely correlates with the availability of shelters (Ryder \& Pesendorfer 1992, Fischer 2000, Cott et al. 2015). It is predominantly nocturnal (Müller 1978, Slavík et al. 2005, Eick 2013, Cott et al. 2015, Harrison et al. 2016b), and its spawning occurs at night during winter (Maitland \& Campbell 1992) at temperatures of approximately 0 to $4^{\circ} \mathrm{C}$ (McPhail \& Paragamian 2000, Harrison et al. 2016b). In rivers, the species is less active in summer (Bergersen et al. 1993, Slavík \& Bartoš 2002, Hölker et al. 2004, Slavík et al. 2005), while in lakes, its activity can be higher. It searches for hiding places during the day and for food at night to maintain optimal temperature conditions for resource use (Harrison et al. 2013, 2016b, Cott et al. 2015).

In the present study, male and female farmed and wild burbot with a common genetic background were radio-tagged with physiological sensors to estimate their energy consumption. Fish were observed during the whole spawning season from November to January in the Vltava River, Elbe catchment area, Czech Republic. To precisely detect the expected spawning activity and estimate its timing, we observed parallel spontaneous spawning activities of burbot in a seminatural river channel with the same water temperature as its source, the Vltava River, where radio-tagged individuals were also observed. We assumed that if farmed and wild fish displayed differences in behavior during the spawning season, then their energy consumption would also differ, reflecting differences in movement activity and spatial distribution in relation to spawning sites.

\section{MATERIALS AND METHODS}

\subsection{Study area}

The study was carried out in the headwaters of the Vltava River, located in Šumava National Park, 
Czech Republic. The Vltava River is $430.2 \mathrm{~km}$ long with an overall catchment area of $28090 \mathrm{~km}^{2}$. The headwaters consist of mountainous oligotrophic streams with pristine morphologies, with the studied stretch located approximately $15 \mathrm{~km}$ downstream of the river source. The studied stretch is ca. $2.8 \mathrm{~km}$ long with an average discharge of $0.7 \mathrm{~m}^{3} \mathrm{~s}^{-1}$ and an average width of $8 \mathrm{~m}$. The river slope of the studied stretch can reach $26 \%$, with alternating occurrences of rapids and pools. The river bottom consists of sand and gravel and is covered by boulders. The most numerous species is the brown trout Salmo trutta (Linnaeus, 1758), followed by the bullhead Cottus gobio (Linnaeus, 1758), burbot and grayling Thymallus thymallus (Linnaeus, 1758). The seminatural river channel used for monitoring burbot spawning activity is $250 \mathrm{~m}$ long, with a width of $2 \mathrm{~m}$ and depth of 0.2 to $1.2 \mathrm{~m}$; the gravel channel bottom is covered by boulders and enriched by dead wood. The seminatural river channel has a continuous flow of $0.2 \mathrm{~m}^{3}$ $\mathrm{s}^{-1}$ and is supplied by water from the Malá Vltava, a tributary of the Vltava River (Fig. 1). To prevent fish escape, the channel was blocked by standard inflow-outflow obstructions.

\subsection{Fish sampling and habitat measurements}

A total of 26 adult burbot (Table 1) with a common genetic background, including 12 hatchery-reared fish selected to simulate escape and/or restocking (Heggberget et al. 1993, Økland et al. 1995, Horká et al. 2015) and 12 wild fish, were used to study behavior and energy consumption in the wild, and 2 hatchery-reared fish were used to monitor energy consumption during the spawning season in the seminatural river channel. Fish were sexed during the surgical tagging procedure. Hatchery-reared burbot ( 7 females and 7 males) were obtained from a local fish supplier (Borová Lada, Czech Republic). The hatchery is located approximately $800 \mathrm{~m}$ from the studied stretch of the Vltava River and is supplied by water from its tributary, the Malá Vltava (Fig. 1). Wild burbot (6 females and 6 males) were captured with electrofishing techniques $(650 \mathrm{~V}, 4 \mathrm{~A}$, pulsed DC) at the confluence of the Vltava and Malá Vltava rivers on 31 October 2014. All 26 fish were tagged on the day of capture. The fish were anesthetized with 2-phenoxyethanol ( $0.2 \mathrm{ml} \mathrm{l}^{-1}$; Merck KGaA) and then measured (standard length; mean $492 \mathrm{~mm}$ and range 465-601 $\mathrm{mm}$ for farmed fish; mean $472 \mathrm{~mm}$ and range 465-477 $\mathrm{mm}$ for wild fish) and weighed (body mass; mean $881 \mathrm{~g}$ and range 652-1200 $\mathrm{g}$ for farmed

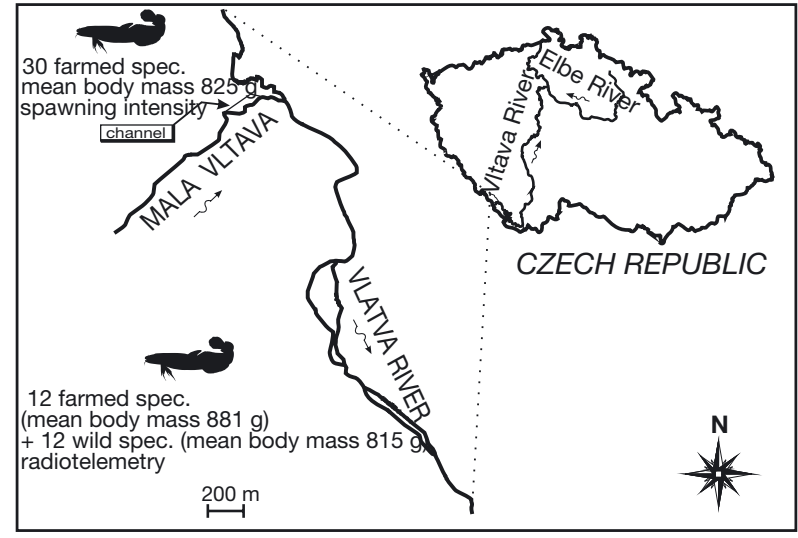

Fig. 1. Study site

fish; mean $815 \mathrm{~g}$ and range $679-1050 \mathrm{~g}$ for wild fish). No body mass differences were detected between the groups (wild $\times$ hatchery reared, $t=1.26, \mathrm{p}=0.22$; male $\times$ female, $t=1.55, \mathrm{p}=0.14)$. The fish were equipped with electromyogram (EMG) transmitters (CEMG2-R11-25; mass $12 \mathrm{~g}$ in air and $5.7 \mathrm{~g}$ in water, $5 \mathrm{~s}$ burst rate, with an operational life of ca. $89 \mathrm{~d}$ ). EMG biotelemetry allows a description of the spatial distribution of fish together with simultaneous measurements of individual energy consumption, measured as the voltage corresponding to muscle activity. EMG transmitters were implanted in the body cavity of each fish through a midventral incision that was closed by 3 or 4 separate stitches using a sterile, braided, absorbable suture (coated VICRYL, Ethicon). The 2 electrodes of the surgically implanted EMG transmitters were positioned in the red aerobic musculature below the lateral line on the left side of the fish. The distance between the electrodes ranged from 10 to $12 \mathrm{~mm}$ (Cooke et al. 2004). The individuals equipped with the EMG transmitters were kept in cages in the river stretch for ca. $30 \mathrm{~min}$ after implantation of the transmitters for recovery (Slavík et al. 2017). They were then released at or near the point of wild fish capture, and 2 hatcheryreared fish were released into the cage in the seminatural river channel. It is recommended that more complete and detailed records be collected for smaller fish patterns when utilizing physiology sensors such as EMG transmitters instead of observing large numbers of individuals at a lower frequency (Cooke et al. 2004). The importance of telemetry data for field observations of fish behavioral patterns in the wild was shown by earlier studies with a smaller number of tracked fish (Slavík \& Horký 2009, O'Neill et al. 2018). 
Table 1. Tagged individuals of burbot with their sex, origin, body mass, standard length (SL), estimated time of death and number of weekly tracking cycles (all and during expected spawning intensities). Two individuals (nos. 25, 26) were used to monitor the energy consumption during spawning season in the seminatural channel. na: not available

\begin{tabular}{|c|c|c|c|c|c|c|c|c|c|}
\hline \multirow{2}{*}{$\begin{array}{l}\text { Fish } \\
\text { no. }\end{array}$} & \multirow[t]{2}{*}{ Sex } & \multirow[t]{2}{*}{ Origin } & \multirow{2}{*}{$\begin{array}{c}\text { Mass } \\
(\mathrm{g})\end{array}$} & \multirow{2}{*}{$\begin{array}{c}\mathrm{SL} \\
(\mathrm{mm})\end{array}$} & \multirow{2}{*}{$\begin{array}{c}\text { Estimated time } \\
\text { of death } \\
\text { (d.mo.) }\end{array}$} & \multicolumn{4}{|c|}{ No. of weekly tracking cycles } \\
\hline & & & & & & $\begin{array}{c}\text { All tracking } \\
\text { cycles }\end{array}$ & None & $\begin{array}{c}\text { - Spawning } \\
\text { Low }\end{array}$ & $\overline{\text { Peak }}$ \\
\hline 1 & Female & Wild & 699 & 465 & na & 11 & 8 & 1 & 2 \\
\hline 2 & Male & Farmed & 746 & 477 & na & 12 & 9 & 1 & 2 \\
\hline 3 & Female & Wild & 728 & 473 & na & 12 & 9 & 1 & 0 \\
\hline 4 & Male & Farmed & 739 & 465 & na & 12 & 9 & 1 & 2 \\
\hline 5 & Female & Wild & 679 & 466 & na & 12 & 9 & 1 & 2 \\
\hline 6 & Male & Farmed & 890 & 490 & 4.11. & na & na & na & na \\
\hline 7 & Male & Wild & 720 & 471 & 4.11 . & na & na & na & na \\
\hline 8 & Male & Farmed & 652 & 473 & na & 12 & 9 & 1 & 2 \\
\hline 9 & Male & Wild & 679 & 468 & 4.11. & na & na & na & na \\
\hline 10 & Female & Farmed & 995 & 477 & 27.11 . & 4 & 4 & 0 & 0 \\
\hline 11 & Male & Wild & 818 & 470 & 4.11. & na & na & na & na \\
\hline 12 & Female & Wild & 906 & 476 & 4.11. & na & na & na & na \\
\hline 13 & Female & Wild & 827 & 470 & 5.12 . & 5 & 5 & 0 & 0 \\
\hline 14 & Male & Farmed & 875 & 465 & 5.12. & 5 & 5 & 0 & 0 \\
\hline 15 & Male & Wild & 852 & 475 & na & 7 & 7 & 0 & 0 \\
\hline 16 & Female & Farmed & 997 & 495 & na & 11 & 8 & 1 & 2 \\
\hline 17 & Female & Farmed & 846 & 495 & na & 6 & 6 & 0 & 0 \\
\hline 18 & Female & Farmed & 1200 & 601 & na & 9 & 8 & 1 & 0 \\
\hline 19 & Male & Wild & 895 & 473 & na & 6 & 6 & 0 & 0 \\
\hline 20 & Male & Wild & 925 & 475 & na & 9 & 8 & 1 & 2 \\
\hline 21 & Female & Farmed & 825 & 537 & na & 12 & 9 & 1 & 2 \\
\hline 22 & Male & Farmed & 1000 & 473 & na & 5 & 5 & 0 & 0 \\
\hline 23 & Female & Farmed & 998 & 500 & na & 12 & 9 & 1 & 2 \\
\hline 24 & Female & Wild & 1050 & 477 & na & 12 & 9 & 1 & 2 \\
\hline 25 & Male & Farmed & 747 & 469 & na & na & na & na & na \\
\hline 26 & Female & Farmed & 819 & 472 & na & na & na & na & na \\
\hline
\end{tabular}

The fish were monitored from 4 November 2014 through 16 January 2015. All individuals were tracked from shores weekly with a radio receiver (SRX_600, Lotek Engineering) and a 3-element Yagi antenna equipped with a compass. The fish were tracked to check their positions during the daylight interval between 11:00 and 14:00 $\mathrm{h}$, and the positions of the fish were determined during 3 subsequent $3 \mathrm{~h}$ nocturnal intervals (19:00-22:00, 22:00-01:00 and 01:00-04:00 h). All tagged fish can be tracked during 1 tracking interval in the context of our study. The data on fish movements were transferred from a GPS device to a PC and analyzed with MapSource version 5.3 (Garmin). A computer program was developed to obtain the positional coordinates of the fish and plot the coordinates on a map with the biangulation method proposed by White \& Garrott (1990). EMG data from the sensor transmitters were stored automatically and subsequently downloaded from the receiver. The accuracy of the determined fish positions was estimated to be $\pm 1 \mathrm{~m}$ according to a calibration procedure performed with a tag located at the river bottom. The calibration was repeated 10 times, and the observer did not know the position of the tag.

\subsection{Monitoring of spawning activity}

The methods required for obtaining reliable estimates of spawning activity (e.g. using nets) in the wild can seriously disturb observed fish, influencing not only their movement but also their EMG values, which are stress sensitive (Slavík et al. 2011). Furthermore, the use of these tools is not permitted by state authorities due to strict regulations for the protected areas of national parks. Hence, only indirect evidence of burbot spawning was obtained, but the undisturbed behavior of fish in the wild was preserved in our study. To estimate the period of spawning, including the period of peak spawning activity, we adopted a seminatural spawning method developed for the support of wild burbot populations in the surrounding Šumava National Park. Before this 
method was applied, it was tested for several years, including tests on the timing of spawning in the wild and under seminatural conditions due to its synchronization. The number of eggs in the wild was checked by drift nets, while the number of eggs in the hatchery was checked in the same manner as described further below and used for spawning detection in the present study. The tests revealed no differences, and it appears that burbot spawning is strictly related to water temperature and, more specifically, the decrease in temperature to values of approximately $2^{\circ} \mathrm{C}$ at the end of the calendar year (J. Šperl pers. comm.). Water temperature in the wild as well as in the seminatural conditions is equal (water from the river is directly used in the seminatural channel). The accuracy of the technique was further verified by burbot artificial spawning methodology (Pokorný \& Adámek 1997) as well as by data from our current study (Fig. 2A). The preliminary tests showed that the spawning is strictly related to temperature decrease and is synchronized in the river and in the seminatural conditions. The preliminary tests were conducted in the same facility as was used for spawning detection in the present study.

We used 30 hatchery-reared burbot (mean body mass 825 g, range 490-2010 g) stocked in a seminatural river channel supplied with water from the Malá Vltava River and located within the study area (Fig. 1). The fish were kept in the seminatural river channel until mature. We assumed that spawning in a seminatural channel would be synchronized with spawning in the river because fish in the river and the seminatural channel were exposed to the same water temperatures. Furthermore, the hatcheryreared burbot that were used for spawning detection had the same genetic background as the wild fish (Vltava River origin), allowing us to predict no interpopulation differences in spawning timing between hatchery-reared and wild fish. Burbot are also highly communal during spawning (Maitland \& Campbell 1992), suggesting that wild and farmed fish will spawn at the same time after release into the river. Despite the fact that we expected spawning synchronization in the seminatural channel and Vltava River, we have only indirect evidence of spawning in the river itself. Therefore, hereafter, we use the term expected spawning intensity in the context of our results. Fish were supplied with live food (fish) and were in random contact with predators to simulate natural conditions (as the whole study was located within Šumava National Park, only fencing of the seminatural river channel was allowed by local authorities; hence, random visits by otters, herons and/or other predators occurred during the study). When the water temperature decreased to $4^{\circ} \mathrm{C}$, 8 males and 12 females were caught and placed in a polypropylene cage (length $5 \mathrm{~m}$, width $1.5 \mathrm{~m}$, depth $1 \mathrm{~m}$ ) located in the seminatural river channel. One male and 1 female in the cage were equipped with EMG tags used to monitor energy consumption during spawning. Their EMG values were recorded daily and handled in the same way as the EMG values of individuals tracked in the Vltava River and
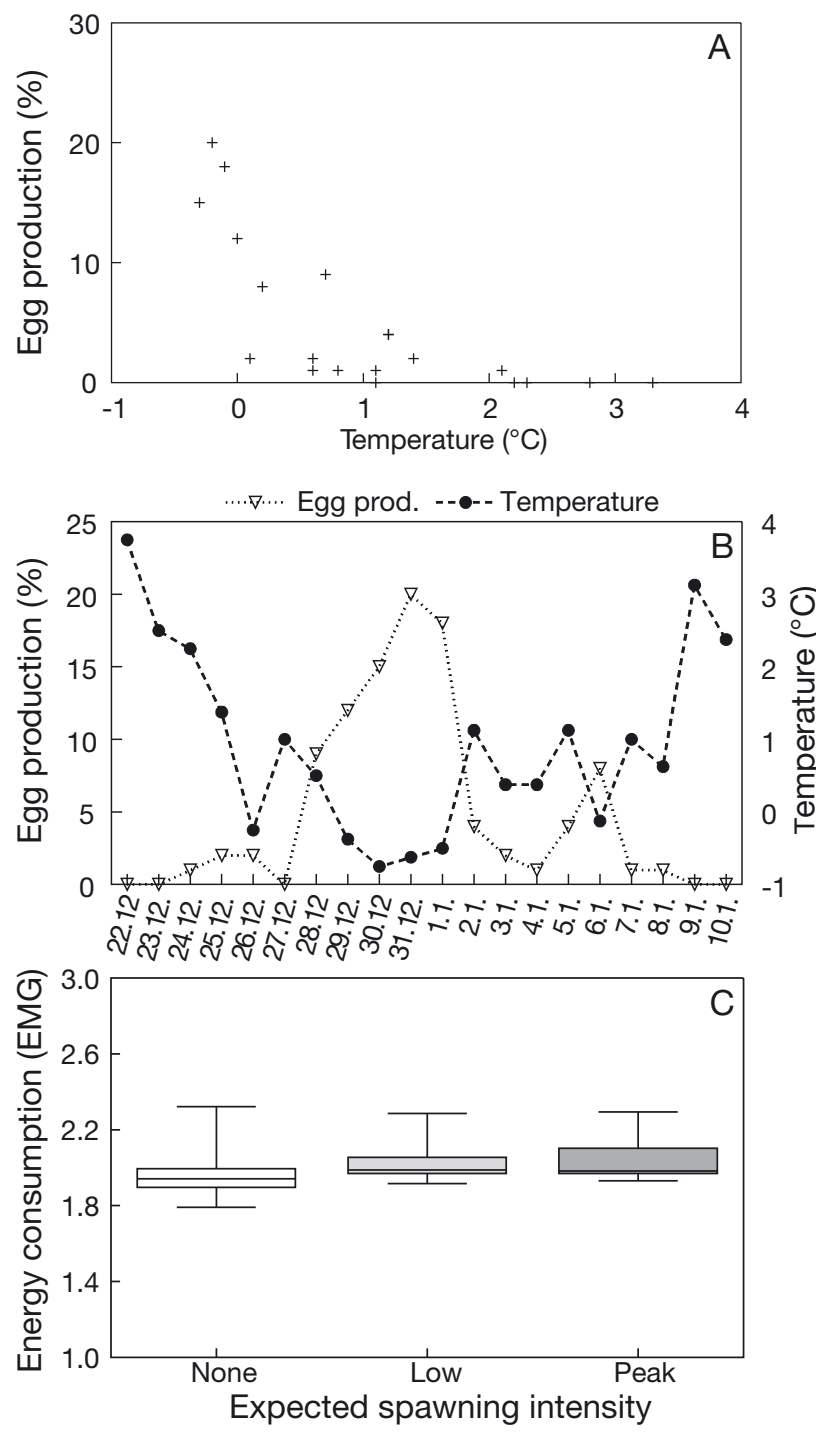

Fig. 2. Raw data of egg production (daily percentage of the whole total no. of eggs gathered during the spawning season), mean daily temperature and electromyogram (EMG) value during spawning in the seminatural river channel. Egg production is (A) plotted against temperature and (B) shown on a daily basis (dates as d.mo.). (C) EMG values across expected spawning intensities are boxplots showing median and interquartile range Q1-Q3 with whiskers from the minimum to maximum 
used as supplementary data for spawning detection (Fig. 2B,C). A net with a mesh size of $100 \mu \mathrm{m}$ was installed at the walls and bottom of the cage. The net was checked every day for the presence of eggs. Any eggs found were gently siphoned into a tank with water using silicone tubing and a large $150 \mathrm{ml}$ injector, and their volume was subsequently measured. Egg abundance was estimated by removing a $1 \mathrm{ml}$ egg volume using a $1 \mathrm{ml}$ injector. Eggs were counted in this subsample (the procedure was repeated 3 times and averaged), and these values were then used to calculate the egg abundance for the whole volume. The methods used are briefly summarized in Table 2 .

\subsection{Data analysis}

The study period was assumed to cover the whole spawning season. In total, 8 tagged individuals were lost during the study. Two individuals died for unknown reasons, and 6 were caught by otters. Five of the fish were lost shortly after tagging and therefore not considered further; the other 3 specimens died during the study, and their data were included for the time period in which they were known to be alive (Table 1). The EMG-coded transmitters allowed multiple transmitters to be monitored simultaneously at the same frequency. Each transmitter had a unique code that served as the fish ID. The intensity of the movements of individual burbot was quantified as the difference $(\mathrm{m})$ between the positions determined in 2 successive tracking intervals and termed movement. The transmitter recorded individual burbot EMG data (range 0-50) every $5 \mathrm{~s}$ (as per Cooke et al. 2004) and then transmitted the value to the receiver, where the data were stored during tracking. To avoid interdependence of consecutive points in the raw

Table 2. Summary of the methods used. EMG: electromyogram

\begin{tabular}{|lcll|}
\hline Environment & $\begin{array}{c}\text { No. of ind. } \\
\text { (origin) }\end{array}$ & Method & Variable \\
\hline River & 12 (wild) & $\begin{array}{c}\text { EMG radio } \\
\text { telemetry }\end{array}$ & $\begin{array}{c}\text { Movement activity } \\
\text { distance between ind.; } \\
\text { energy consumption }\end{array}$ \\
& 12 (farmed) & $\begin{array}{c}\text { EMG radio } \\
\text { telemetry }\end{array}$ & $\begin{array}{c}\text { Movement activity } \\
\text { distance between ind; } \\
\text { energy consumption }\end{array}$ \\
$\begin{array}{c}\text { Seminatural } \\
\text { channel }\end{array}$ & 28 (farmed) & $\begin{array}{c}\text { Egg collection } \\
\text { Egg collection; } \\
\text { EMG radio telemetry }\end{array}$ & $\begin{array}{c}\text { Spawning intensity } \\
\text { Spawning intensity; } \\
\text { energy consumption }\end{array}$ \\
\hline
\end{tabular}

continuous data (a type of $m$-dependence structure; Moon \& Velasco 2013), a regular interval grid approach was applied. Thus, every fish was assigned 1 mean field EMG value in every tracking interval (3 subsequent $3 \mathrm{~h}$ nocturnal intervals). To obtain information on the resting activity levels for standardizing data, the EMG transmitters were individually calibrated for each fish. The resting values were measured twice: from anesthetized fish and prior to release, when the fish were held in cages. The average of all recorded EMG resting signals was subsequently considered the baseline value for the fish and is henceforth termed the baseline EMG value (Cooke et al. 2004). Each final EMG value included in the subsequent analysis was equal to the field EMG value minus the baseline EMG value. To ensure that the individual EMG consumption analyses were independent of weight, relative EMG:weight ratios were calculated by dividing each final EMG value by fish weight (e.g. Aarestrup et al. 2005). An analogous approach was used for fish movement, producing relative movement:weight ratios. The EMG:weight ratios were used as general descriptors of energy consumption, and the movement:weight ratios were used as general descriptors of movement activity. Based on the fish positions, the distance between individuals (m) was obtained. Distances between individuals were assigned for all combinations of individuals tracked over $24 \mathrm{~h}$ tracking cycles (i.e. if 3 individuals [1,2 and 3] were tracked, 3 distances between individuals $[1-2,1-3$ and 2-3] were obtained during the tracking interval). Distance between individuals is an indicative measure of social contacts within the observed population. It should not be interpreted as an absolute distance, as there can also be other (i.e. non-tagged) individuals present. It also does not show 'who-withwhom' is spawning.

Data from spawning activity monitoring in the seminatural river channel were used to determine the expected spawning intensity in the wild, which was assigned as a 3-level class variable, from none (no eggs were observed) to low (eggs were observed, but the egg production per day of the spawning season was lower than its 3 highest values) to expected spawning peak (the 3 highest values of egg production per day of the spawning season were observed on 30 and 31 Dec 2014 and 1 Jan 2015; Fig. 2B). 
Fish origin was assigned as a 2-level class variable distinguishing between farmed and wild fish.

\subsection{Statistical analyses}

Statistical analyses were performed using the SAS software package (SAS Institute, version 9.4, www. sas.com). Separate linear mixed models (LMMs) with random factors (PROC MIXED) were fitted with movement activity, distance between individuals and energy consumption as dependent variables. The data were transformed for normality prior to the LMM analyses when necessary $\left(\log _{10}\right.$ movement activity, square root distance between individuals, $\log _{10}$ energy consumption). The random factors were used to account for repeated measures of the same experimental units (individual fish) throughout the experiment. In repeated-measures experiments with people or animals as subjects, subjects are declared random because they are selected from the larger population to which the outcome is generalized (SAS Institute 2004). The significance of each explanatory variable (fish origin, sex, expected spawning intensity and their possible 2-way interactions) was assessed using an F-test. Fixed effects and their interactions that were not statistically significant were removed, and the model was refit without them; therefore, these effects and interactions are not discussed further. The design of field studies is unbalanced with respect to unpredictable external factors (e.g. predation and the unavailability of an individual for regular tracking). In unbalanced study designs with more than 1 effect, the arithmetic mean of a group may not accurately reflect the response of that group because other effects are unaccounted for. Therefore, least square means (LSMs) were used. LSMs (henceforth referred to as adjusted means) are, in effect, within-group means appropriately adjusted for the other effects in the model computed for each significant class of exploratory variables. The differences between classes were tested with $t$-tests, and a Tukey-Kramer adjustment, henceforth referred to as adj. p, was used for multiple comparisons. The df was calculated using the KenwardRoger method (Kenward \& Roger 1997).

\section{RESULTS}

\subsection{Monitoring of spawning activity}

Total egg production was estimated to be 9.2 million, with the percent distribution per day of the spawning season documented in Fig. 2B. Spawning took place during the period from 24 December 2014 to 8 January 2015 at water temperatures ranging from -0.3 to $2.6^{\circ} \mathrm{C}$. The energy consumption of hatchery-reared burbot in the seminatural river channel did not show any clear trend during the spawning season and did not change across the expected spawning intensity (Fig. 2C; none-low, $t=$ $0.19, \mathrm{p}=0.85$; none-peak $, t=0.07, \mathrm{p}=0.95$; low-peak, $t=-0.41, \mathrm{p}=0.69$ ).

\subsection{Movement activity}

The movement activity of burbot decreased throughout the nocturnal intervals $\left(F_{2,389}=3.2, \mathrm{p}=\right.$ 0.042; adj. $\mathrm{p}<0.05$; Fig. 3A). Movement activity also differed between wild and farmed conspecifics across sexes $\left(F_{2,19.1}=7.43, \mathrm{p}=0.004 ;\right.$ Fig. $\left.3 \mathrm{~B}\right)$ and expected spawning intensities $\left(F_{4,396}=3.7, \mathrm{p}=0.006\right.$; Fig. 3C). Across the whole spawning season, farmed females showed lower movement activity than wild females and farmed males (adj. p < 0.05; Fig. 3B). Wild burbot showed a decrease in movement activity during the expected spawning peak (adj. p < 0.05), while farmed burbot showed a decrease in activity during low spawning intensity (adj. p < 0.05) and an increase again during the expected spawning peak (adj. p > 0.9; Fig. 3C).

\subsection{Distance between individuals}

Our results showed larger spatial separation of farmed and wild fish than the separation of individuals within both groups (farmed and wild) across the whole spawning season $\left(F_{2,1946}=21.32\right.$, $\mathrm{p}<0.0001$; Fig. 4A). The shortest mutual distance between farmed individuals was recorded for females (adj. $\mathrm{p}<0.01$ ), while for wild fish, it was recorded between sexes $\left(F_{4,1451}=25.49, \mathrm{p}<0.0001\right.$; adj. p $<0.01$; Fig. 4B). Spatial separation increased within all groups (farmed, wild, and farmed and wild) with expected spawning intensity $\left(F_{4,3114}=\right.$ 35.21, $\mathrm{p}<0.0001$; Fig. 4C). Additionally, the distance between males, females or between sexes generally increased with expected spawning intensity $\left(F_{4,3118}=27.60, \mathrm{p}<0.0001\right.$; Fig. $\left.4 \mathrm{D}\right)$. This effect was most intense in males that were more separated during the expected spawning peak than females (adj. $p<0.0001$ ) or females and males (adj. $\mathrm{p}<0.0001$ ), whose distance was comparable (adj. $\mathrm{p}>0.9$ ). 


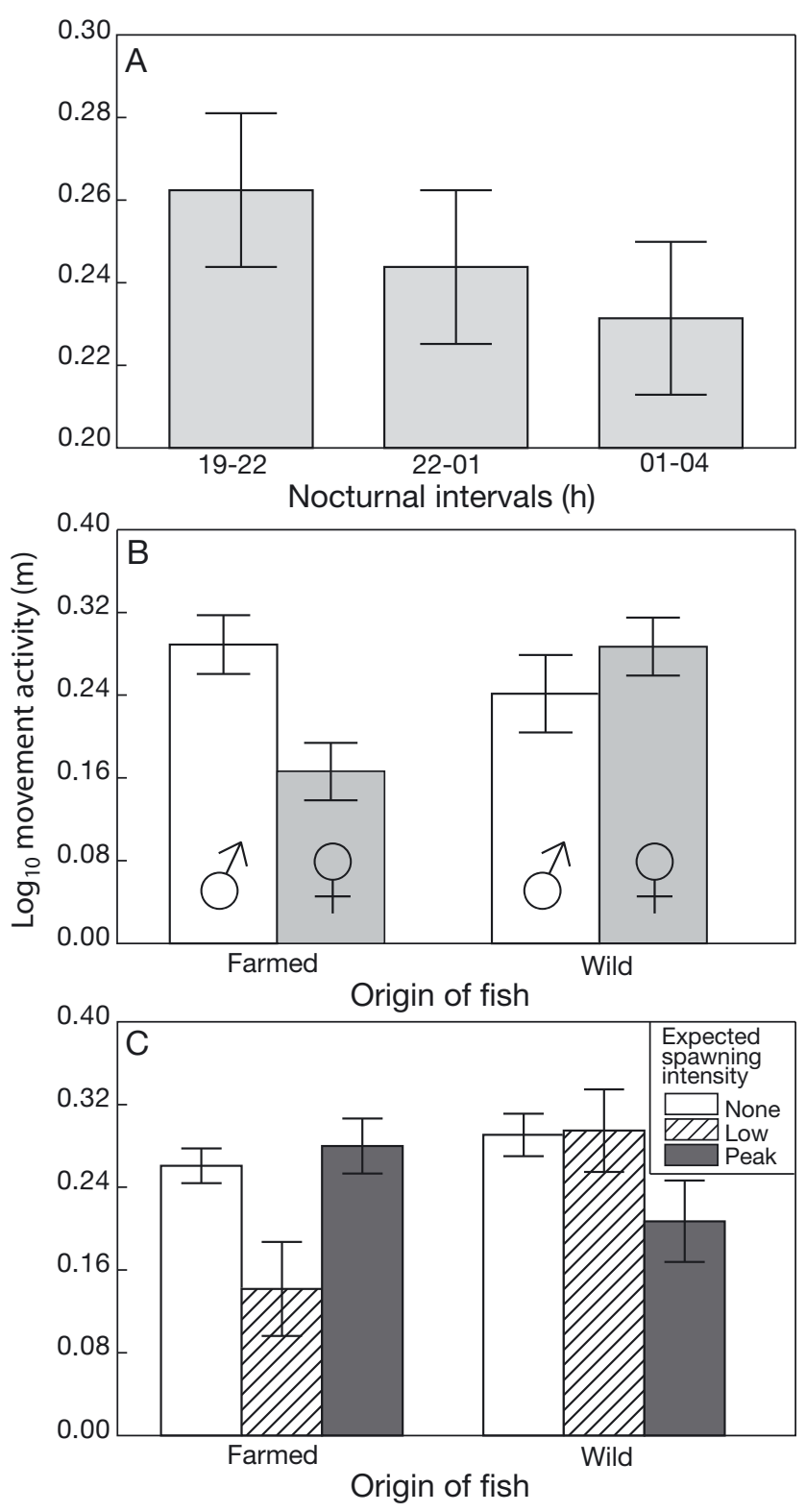

Fig. 3. Burbot movement activity across (A) night intervals, (B) fish origin and sex and (C) fish origin and spawning intensity. Values are adjusted means $( \pm \mathrm{SE})$ from $\log _{10^{-}}$ transformed movement activity data

\subsection{Energy consumption}

Increased energy consumption was observed over the expected peak of spawning for wild burbot $\left(F_{4,355}=3.43, \mathrm{p}=0.009 ;\right.$ adj. $\mathrm{p}<0.01$; Fig. 5A $)$, while farmed fish showed no significant changes in energy consumption according to expected spawning intensity (adj. p > 0.9; Fig. 5A). Across the whole spawning season, farmed females showed lower energy consumption than wild females $\left(F_{2,57.2}=20.73, \mathrm{p}<0.0001\right.$; adj. p $<0.01$; Fig. 5B), and the opposite results were found for farmed males (adj. $\mathrm{p}<0.01$; Fig. 5B).

\section{DISCUSSION}

\subsection{Movement activity}

In central Europe, burbot display mostly nocturnal activity (Müller 1978, Eick 2013) that peaks after dusk and subsequently decreases (Slavík et al. 2005), which corresponds with our results during the whole spawning season. Specimens from both groups (wild and farmed) were distributed within a few kilometers long stretch along the longitudinal profile of the river, which is typical for fish migrations in headwaters (Northcote 2010) and consistent with the findings of earlier studies of salmonids in the study area (Slavík et al. 2012, 2018). Farmed burbot displayed higher movement activity during the expected spawning peak than their wild conspecifics, which agrees with the general assumption of higher investment in movement and a less successful spawning process in farmed fish. Differences in spawning strategies between sexes have been reported for wild fish, e.g. for salmonids (Fleming 1996, Esteve 2005); similarly, in farmed fish, the sexes differ in spawning behavior (Fleming et al. 1994, Skjæraasen et al. 2010b, Christie et al. 2014, Wringe et al. 2015). Hence, when we analyzed movement activity separately for sexes and across the whole spawning season, higher movement occurred for farmed males, presumably indicating limited association with spawning sites as recorded, e.g. for salmon (Jonsson et al. 1990, Økland et al. 1995, Thorstad et al. 1998). In cod Gadus morhua, more frequent refusal of farmed males by wild females (Skjæraasen et al. 2010b) can be related to their recorded higher movement activity. Furthermore, wild females were more active than farmed females, which corresponds with the activity described in salmonids wherein wild females were more active during reproduction (Fleming et al. 1994, Gross 1998). Moreover, the higher movement activity of wild females compared to wild males may be associated with the search for spawning areas, as reported for salmonids (Karppinen et al. 2004, Moe et al. 2016). Our results suggest a lower association of farmed males with spawning sites, resulting in an increase in their movement activity; the lower movement of farmed females was likely indicative of reduced spawning effort. As reported in an earlier study, farmed burbot stocked within a restoration program and observed with telemetry were able to find historical spawning sites of the native population (Neufeld et al. 2011, Hardy et al. 2015). The difference in 

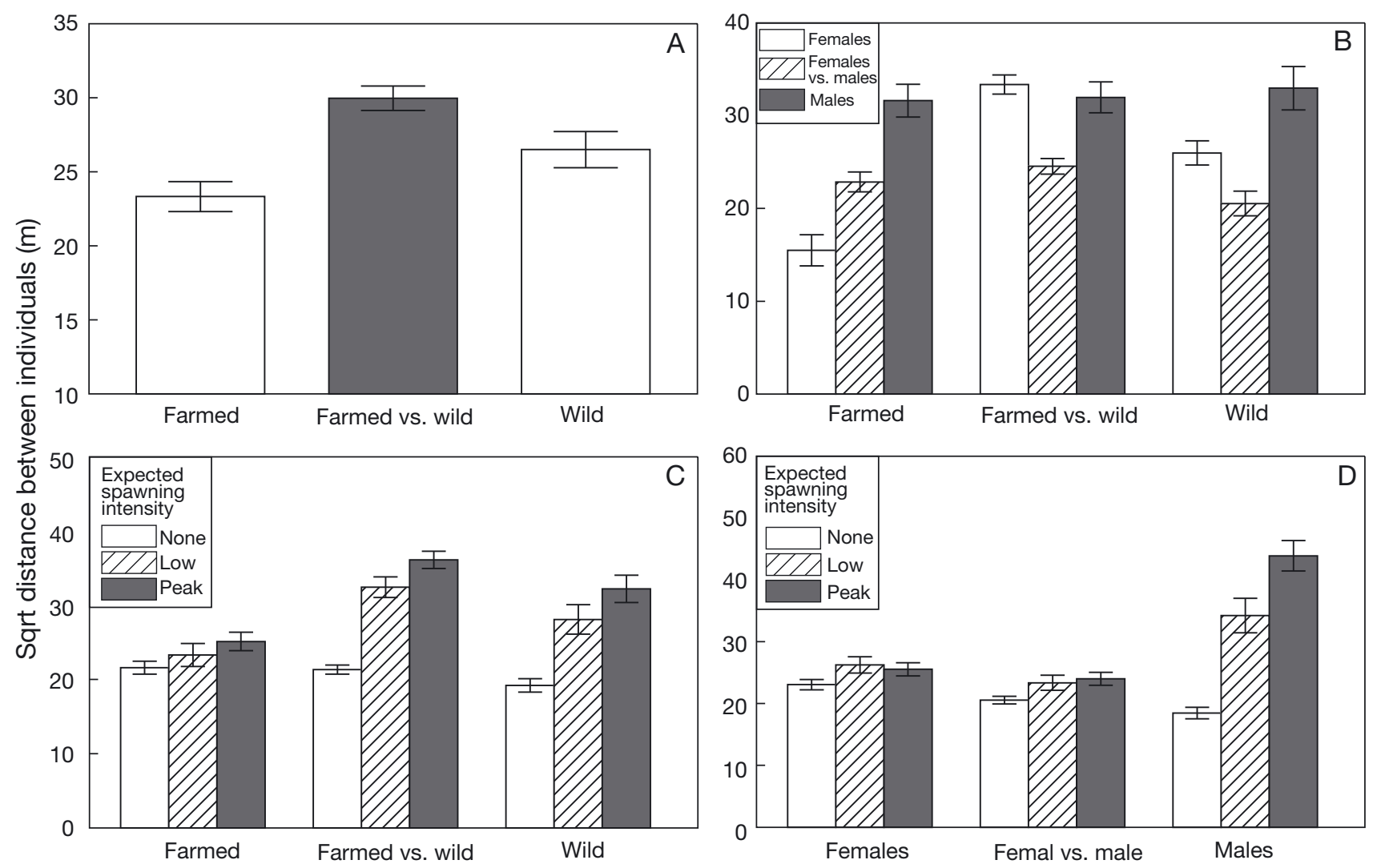

Fig. 4. Distance (A) between individuals of various origins, (B) across various origins and sexes, (C) across various origins and spawning intensities and (D) across sexes and spawning intensities. Values are adjusted means ( \pm SE) from square root transformed distances between individual data

behavior of burbot in the present study can be attributed to our simulation of escape from aquaculture and use of adult farmed individuals for observations, while the restoration program used hatchery-originated burbot that grew and matured in the wild.

\subsection{Distances between individuals}

Different spatial distributions of hatchery-originated fish compared to wild conspecifics can be considered a potential limitation of their successful spontaneous reproduction in native environments (Berejikian et al. 2001, Moe et al. 2016). Our results showed larger spatial separation of farmed and wild fish than of individuals within each group (farmed and wild). Moreover, the shortest mutual

Fig. 5. Burbot energy consumption across (A) fish origins and spawning intensities and (B) fish origins and sexes. Values are adjusted means $( \pm \mathrm{SE})$ from $\log _{10}$-transformed energy consumption data. EMG: electromyogram

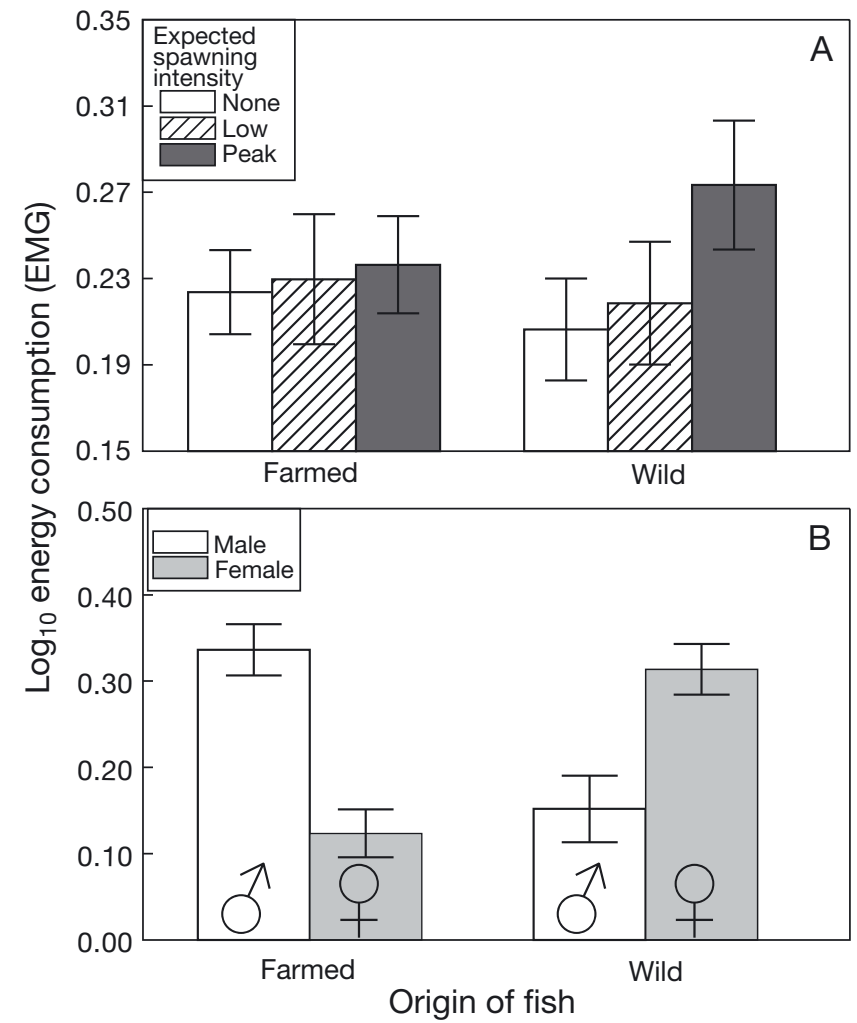


distance between farmed individuals was recorded for females, while for wild fish, it was recorded between sexes. Spatial separation of sexes around a spawning area has been reported for marine relatives of burbot, such as Atlantic cod, with the observed positions of wild males during spawning being deeper and closer to the bottom than those of farmed conspecifics (Meager et al. 2009). Similarly, the observed positions of cod in relation to a spawning area showed larger dispersion and a more pelagic occurrence of wild females; however, farmed females were more frequently found outside the spawning area (Meager et al. 2010). Furthermore, after a simulated escape, farmed cod displayed broader dispersion than their wild conspecifics (Uglem et al. 2008). In contrast, no differences in the dispersion of males and females between farmed and wild cod were reported (Skjæraasen et al. 2011). Spawning in groups and compact clusters evocative of a lekking system has also been reported for burbot in rivers (Maitland \& Campbell 1992). In our study, distance between sexes differed, being the closest between wild males and females, while for farmed fish, the closest positions were recorded between females. As reported for salmons, farmed females may not participate in reproduction in the wild (Jonsson et al. 1990). In our study, wild burbot, especially males, were more widely spread in the stream during the expected peak of spawning activity. Similarly, the spawning distribution of female spring Chinook salmon Oncorhynchus tshawytscha (Walbaum, 1792) reflected fish origin and showed an upstream distribution of wild fish in natural pool-riffle channels, while farmed females were distributed only in the lower watershed with plane bed channels, presumably more similar to hatchery conditions (Hughes \& Murdoch 2017). Different spatial distributions of farmed burbot throughout the spawning season, including during the expected spawning peak, suggested a lower association of both sexes for farmed compared to wild fish.

Telemetry methods are useful techniques with a potential to provide interesting data about the mutual spatial distribution of tagged individuals in natural conditions (Slavík et al. 2007, 2018). However, obtained results should be interpreted as an indicative measure of social contacts within observed populations in the wild, as there can also be other non-tagged individuals present. Despite this limitation, radio telemetry can provide information about the spatial distribution of fish together with a simultaneous measurement of other variables such as individual energy consumption (Slavík \& Horký 2009).

\subsection{Energy consumption}

Farmed fish typically invest more energy into territorial conflicts than wild fish without increasing the probability of winning and maintaining food resources (Deverill et al. 1999, Sundström et al. 2003, Lorenzen et al. 2012). Similarly, they also invest more into reproductive processes with limited success compared to their wild conspecifics (Fleming \& Petersson 2001, Weir et al. 2004, Jonsson \& Jonsson 2006). Our results revealed differences in energy consumption between farmed and wild burbot. Energy consumption during the expected spawning peak significantly increased only for wild fish. Higher EMG values can be related to reproductive behavior and increased physical activity of spawning individuals, as reported for salmonids (Kaseloo et al. 1996, Weatherley et al. 1996, Berejikian et al. 2007). The EMG records collected during the expected spawning peak thus indicated that only wild fish spawned. In salmonids, differences in reproductive behavior between sexes were associated with different levels of energy consumption (Healey et al. 2003). In our study, differences in energy consumption between sexes were found when considering the whole spawning season. Farmed males showed higher energy consumption, while farmed females had lower energy consumption than their wild conspecifics. Similarly, cod male behavior during reproduction was accompanied by mass loss, suggesting energetically demanding reproduction for males irrespective of their origin (Skjæraasen et al. 2010a). Differences in energy input to the reproductive process between farmed and wild burbot can be anticipated; however, disentangling the underlying reasons for these differences with respect to the field study characteristics is complex. Although the relationship between energy consumption and movement activity during the spawning season appears to be a key issue, EMG records do not always necessarily correlate with changes in spatial position reliably determined by tag signals (approximately 1-2 m); hence, further conclusions are difficult to interpret and decipher. For example, the long-term maintenance of positions at spawning sites accompanied by minimal movement activity was revealed as a highly energy-intensive process during salmon reproduction, in contrast to energetically demanding antago- 
nistic behaviors (e.g. chasing) performed for only a short time (Healey et al. 2003). Correspondingly, the amount of energy consumed by the European catfish Silurus glanis (Linnaeus, 1758) to defend food resources within its core area was lower than the amount of energy consumed during inspectional swimming at the peripheries of its home range (Slavík et al. 2014).

\section{CONCLUSIONS}

Currently, the burbot is introduced as a part of many restoration programs aimed at strengthening waning wild populations as a result of habitat losses and/or overfishing. Moreover, this species is produced in aquaculture, which poses a risk of farmed fish escaping into the wild. Restoration programs have shown success in terms of the search for native spawning sites by hatchery-originated individuals that grew and matured in the wild. According to our results, compared with wild conspecifics, adult farmed burbot that escaped to the wild displayed differences in movement activity and spatial distribution during the spawning season. Furthermore, the energy consumption of farmed fish differed between sexes and tended to show differences in response to spawning conditions. These differences indicate a potentially limited success of farmed fish in the wild when searching for resources such as spawning sites and partners.

Acknowledgements. The study was financially supported by the European Regional Development Fund Project 'Centre for the investigation of synthesis and transformation of nutritional substances in the food chain in interaction with potentially harmful substances of anthropogenic origin: comprehensive assessment of soil contamination risks for the quality of agricultural products' (No. CZ.02.1.01/0.0/0.0). The authors thank N. Pfauserová for data processing and A. Slavikova for providing assistance with earlier versions of the manuscript. The authors also thank the technical staff of the hatchery in Šumava National Park, namely J. Šperl and Z. Janči.

\section{LITERATURE CITED}

Aarestrup K, Jepsen N, Rasmussen G, Økland F, Thorstad EB, Holdernsgaard G (2000) Prespawning migratory behaviour and spawning success of sea-ranched Atlantic salmon, Salmo salar L., in the River Gudenaa, Denmark. Fish Manag Ecol 7:387-400

Aarestrup K, Jepsen N, Koed A, Pedersen S (2005) Movement and mortality of stocked brown trout in a stream. J Fish Biol 66:721-728

Araki H, Schmid C (2010) Is hatchery stocking a help or a harm? Evidence, limitations and future directions in eco- logical and genetic surveys. Aquaculture 308(Suppl): $\mathrm{S} 2-\mathrm{S} 11$

Araki H, Cooper B, Blouin MS (2007) Genetic effects of captive breeding cause a rapid, cumulative fitness decline in the wild. Science 318:100-103

Berejikian AB, Tezak EP, Schroder SL (2001) Reproductive behavior and breeding success of captively reared Chinook salmon. N Am J Fish Manage 21:255-260

Berejikian AB, Endicott RC, Van Doornick DM, Brown RS, Tatara CP, Atkins J (2007) Spawning by female Chinook salmon can be detected by electromyogram telemetry. Trans Am Fish Soc 136:593-605

*Bergersen EP, Cook MF, Baldes RJ (1993) Winter movements of burbot (Lota lota) during an extreme drawdown in Bull Lake, Wyoming, USA. Ecol Freshwat Fish 2: $141-145$

* Blábolil P, Duras J, Jůza T, Kocvara L and others (2018) Assessment of burbot Lota lota (L. 1758) population sustainability in central European reservoirs. J Fish Biol 92: 1545-1559

Brockmark S, Johnsson IJ (2010) Reduced hatchery rearing density increases social dominance, post release growth, and survival in brown trout (Salmo trutta). Can J Fish Aquat Sci 67:288-295

*Buhle ER, Holsman KK, Scheuerell MD, Albaugh A (2009) Using an unplanned experiment to evaluate the effects of hatcheries and environmental variation on threatened populations of wild salmon. Biol Conserv 142:2449-2455

Christie MR, Ford MJ, Blouin MS (2014) On the reproductive success of early-generation hatchery fish in the wild. Evol Appl 7:883-896

Cooke SJ, Thorstad EB, Hinch SG (2004) Activity and energetics of free-swimming fish insights from electromyogram telemetry. Fish Fish 5:21-52

* Cott PA, Johnston TA, Gunn JM (2013) Stability in life history characteristics among burbot populations across environmental gradients. Trans Am Fish Soc 142: 1746-1756

Cott PA, Guzzo MM, Chapelsky AJ, Milne SW, Blanchfield PJ (2015) Diel bank migration of burbot (Lota lota). Hydrobiologia 757:3-20

* Deverill JI, Adams CE, Bean CW (1999) Prior residence, aggression and territory acquisition in hatchery-reared and wild brown trout. J Fish Biol 55:868-875

* Diserud OH, Fiske P, Sćgrov H, Urdal K and others (2019) Escaped farmed Atlantic salmon in Norwegian rivers during 1989-2013. ICES J Mar Sci 76:1140-1150

* Eick D (2013) Habitat preferences of the burbot (Lota lota) from the river Elbe: an experimental approach. J Appl Ichthyol 29:541-548

Einum S, Fleming IA (2001) Implications of stocking: ecological interactions between wild and released salmonids. Nord J Freshw Res 75:56-70

Esteve M (2005) Observations of spawning behaviour in Salmoninae: Salmo, Oncorhynchus and Salvelinus. Rev Fish Biol Fish 15:1-21

Fischer P (2000) An experimental test of metabolic and behavioural responses of benthic fish species to different types of substrate. Can J Fish Aquat Sci 57:2336-2344

*Fleming IA (1996) Reproductive strategies of Atlantic salmon: ecology and evolution. Rev Fish Biol Fish 6: 379-416

* Fleming IA, Gross MR (1993) Breeding success of hatchery and wild coho salmon (Oncorhynchus kisutch) in competition. Ecol Appl 3:230-245 
Fleming IA, Petersson E (2001) The ability of released, hatchery salmonids to breed and contribute to the natural productivity of wild populations. Nord J Freshw Res 75:71-98

Fleming IA, Jonsson B, Gross MR (1994) Phenotypic divergence of sea-ranched, farmed, and wild salmon. Can J Fish Aquat Sci 51:2808-2824

Fleming IA, Lamberg A, Jonsson B (1997) Effects of early experience on the reproductive performance of Atlantic salmon. Behav Ecol 8:470-480

Gross MR (1998) One species with two biologies: Atlantic salmon (Salmo salar) in the wild and in aquaculture. Can J Fish Aquat Sci 55(Suppl 1):131-144

*Hardy SR, Paragamian VL (2013) A synthesis of Kootenai River burbot stock history and future management goals. Trans Am Fish Soc 142:1662-1670

Hardy SR, Stephenson MS, Neufeld DM, Young PS (2015) Adaptation of lake-origin burbot stocked into a large river environment. Hydrobiologia 757:35-47

Harrison PM, Gutowsky LF, Martins EG, Patterson DA, Leake A, Cooke SJ, Power M (2013) Diel vertical migration of adult burbot: a dynamic trade-off among feeding opportunity, predation avoidance, and bioenergetic gain. Can J Fish Aquat Sci 70:1765-1774

Harrison PM, Gutowsky LFG, Martins EG, Patterson DA, Cooke SJ, Power M (2015) Personality-dependent spatial ecology occurs independently from dispersal in wild burbot (Lota lota). Behav Ecol 26:483-492

"Harrison PM, Gutowsky LF, Martins EG, Patterson DA, Cooke SJ, Power M (2016a) Burbot and large hydropower in North America: benefits, threats and research needs for mitigation. Fish Manag Ecol 23:335-349

Harrison PM, Gutowsky LF, Martins EG, Patterson DA, Cooke SJ, Power M (2016b) Temporal plasticity in thermal-habitat selection of burbot Lota lota a diel-migrating winter-specialist. J Fish Biol 88:2111-2129

Healey MC, Lake R, Hinch SG (2003) Energy expenditures during reproduction by sockeye salmon (Oncorhynchus nerka). Behaviour 140:161-182

Heggberget TG, Økland F, Ugedal O (1993) Distribution and migratory behaviour of adult wild and farmed Atlantic salmon (Salmo salar) during return migration. Aquaculture 118:73-83

Hindar K, Fleming IA, McGinnity P, Diserud O (2006) Genetic and ecological effects of salmon farming on wild salmon: modelling from experimental results. J Mar Sci 63:1234-1247

Hölker F, Volkmann S, Wolter C, van Dijk PLM, Hardewig I (2004) Colonization of the freshwater environment by a marine invader: how to cope with warm summer temperatures? Evol Ecol Res 6:1123-1144

Horká P, Horký P, Randák T, Turek J, Rylková K, Slavík O (2015) Radio-telemetry shows differences in the behaviour of wild and hatchery-reared European grayling Thymallus thymallus in response to environmental variables. J Fish Biol 86:544-557

Hughes MS, Murdoch AR (2017) Spawning habitat of hatchery spring Chinook salmon and possible mechanisms contributing to lower reproductive success. Trans Am Fish Soc 146:1016-1027

Huntingford FA (2004) Implications of domestication and rearing conditions for the behaviour of cultivated fishes. J Fish Biol 65:122-142

Jensen Ø, Dempster T, Thorstad EB, Uglem I, Fredheim A (2010) Escapes of fishes from Norwegian sea-cage aqua- culture: causes, consequences and prevention. Aquacult Environ Interact 1:71-83

* Johnsson JI, Brockmark S, Nãslund J (2014) Environmental effects on behavioural development consequences for fitness of captive-reared fishes in the wild. J Fish Biol 85: 1946-1971

Jonsson B, Jonsson N (2006) Cultured Atlantic salmon in nature: a review of their ecology and interaction with wild fish. ICES J Mar Sci 63:1162-1181

Jonsson B, Jonsson N (2017) Maternal inheritance influences homing and growth of hybrid offspring between wild and farmed Atlantic salmon. Aquacult Environ Interact 9:231-238

Jonsson B, Jonsson N, Hansen LP (1990) Does juvenile experience affect migration and spawning of adult Atlantic salmon? Behav Ecol Sociobiol 26:225-230

Jonsson N, Jonsson B, Hansen LP (2003) Atlantic salmon straying from the River Imsa. J Fish Biol 62:641-657

Karppinen P, Erkinaro J, Niemela E, Moen K, Økland F (2004) Return migration of one-sea-winter Atlantic salmon in the River Tana. J Fish Biol 64:1179-1192

Kaseloo PA, Weatherley AH, Ihssen PE, Anstey DA, Gare MD (1996) Electromyograms from radiotelemetry as indicators of reproductive activity in lake trout. J Fish Biol 48:664-674

Kenward MG, Roger JH (1997) Small sample inference for fixed effects from restricted maximum likelihood. Biometrics 53:983-997

Kihslinger RL, Newitt GA (2006) Early rearing environment impacts cerebellar growth in juvenile salmon. J Exp Biol 209:504-509

Kucharczyk D, Nowosada J, Kujawaa R, Dietricha G and others (2018) Comparison of spontaneous and hormoneinduced reproduction of burbot (Lota lota L.) under hatchery conditions. Aquaculture 485:25-29

Lehtonen H (1998) Winter biology of burbot (Lota lota L.). Memo Soc Fauna Flora Fenn 74:45-52

*Lorenzen K, Beverige MCM, Mangel M (2012) Cultured fish: integrative biology and management of domestication and interactions with wild fish. Biol Rev Camb Philos Soc 87:639-660

* Lura H, Saegrov H (1993) Timing of spawning in cultured and wild Atlantic salmon (Salmo salar) and brown trout (Salmo trutta) in the River Vosso, Norway. Ecol Freshwat Fish 2:167-172

Maitland PS, Campbell RN (1992) Freshwater fishes. Harper Collins, London

*McGinnity P, Prodöhl P, Ferguson A, Hynes R and others (2003) Fitness reduction and potential extinction of wild populations of Atlantic salmon, Salmo salar, as a result of interactions with escaped farm salmon. Proc R Soc B 270: 2443-2450

McLean J, Bentzen P, Quinn TP (2003) Differential reproductive success of sympatric, naturally spawning hatchery and wild steelhead trout (Oncorhynchus mykiss) through the adult stage. Can J Fish Aquat Sci 60: 433-440

McPhail JD, Paragamian VL (2000) Burbot biology and life history. In: Paragamian VL, Willis WD (eds) Burbot: biology, management, and ecology. Am Fish Soc, Fish Manage Sect Publ 1, Bethesda, MD, p 11-23

Meager JJ, Skjæraasen JE, Fernö A, Karlsen Ø, Løkkeborg S, Michalsen K, Utskot SO (2009) Vertical dynamics and reproductive behaviour of farmed and wild Atlantic cod Gadus morhua. Mar Ecol Prog Ser 389:233-243 
Meager JJ, Skjæraasen JE, Fernö A, Løkkeborg S (2010) Reproductive interactions between fugitive farmed and wild Atlantic cod (Gadus morhua) in the field. Can J Fish Aquat Sci 67:1221-1231

* Moe K, Næsje TF, Haugen TO, Ulvan EM, Aronsen T, Sandnes T, Thorstad EB (2016) Area use and movement patterns of wild and escaped farmed Atlantic salmon before and during spawning in a large Norwegian river. Aquacult Environ Interact 8:77-88

Moon S, Velasco C (2013) Tests for m-dependence based on sample splitting methods. J Econom 173:143-159

Müller K (1978) The flexibility of the circadian system of fish at different latitudes. In: Thorpe JE (ed) Rhythmic activity of fishes. Academic Press, London, p 91-104

Neufeld MD, Cain DK, Jensen RN, Ireland CS, Paragamian VL (2011) Movement of lake-origin burbot reared in a hatchery environment and released into a large river drainage. N Am J Fish Manage 31:56-62

Northcote TG (2010) Controls for trout and char migratory/ resident behavior mainly in stream systems above and below waterfalls/barriers: a multi-decadal and broad geographical review. Ecol Freshwat Fish 19:487-509

* O'Neill R, Ó'Maoiléidigh N, McGinnity P, Bond N, Culloty S (2018) The novel use of pop-off satellite tags (PSATs) to investigate the migratory behaviour of European sea bass Dicentrarchus labrax. J Fish Biol 92:1404-1421

Økland F, Heggberget TG, Jonsson B (1995) Migratory behaviour of wild and farmed Atlantic salmon (Salmo salar) during spawning. J Fish Biol 46:1-7

Pokorný J, Adámek Z (1997) Artificial spawning of burbot and breeding of its fry. Edice Metodik, VURH, Vodňany 53:1-11 (in Czech)

Quinn TP (1993) A review of homing and straying in hatchery-produced salmon. Fish Res 18:29-44

Ryder RA, Pesendorfer J (1992) Food, growth, habitat, and community interaction of young-of-the-year burbot, Lota lota L., in a Precambrian shield lake. Hydrobiologia 243: 211-227

SAS Institute (2004) SAS/STAT® 9.1 user's guide. SAS Institute, Cary, NC

Skaala Ø, Taggart J, Gunnes K (2005) Genetic difference between five major domesticated strains of Atlantic salmon and wild salmon. J Fish Biol 67:118-128

Skjæraasen JE, Meager JJ, Hutchings JA (2010a) A cost of reproduction in male Atlantic cod (Gadus morhua). Can J Zool 88:595-600

Skjæraasen JE, Meager JJ, Karlsen Ø, Mayer I, Dahle G, Rudolfsen G, Fernö A (2010b) Mating competition between farmed and wild cod Gadus morhua. Mar Ecol Prog Ser 412:247-258

Skjæraasen JE, Meager JJ, Karlsen Ø, Hutchings JA, Fernö A (2011) Extreme spawning-site fidelity in Atlantic cod. ICES J Mar Sci 68:1472-1477

Slavík O, Bartoš L (2002) Factors affecting migrations of burbot. J Fish Biol 60:989-998

Klavík O, Horký P (2009) When fish meet fish as determined by physiological sensors. Ecol Freshwat Fish 18:501-506

* Slavík O, Bartoš L, Mattas D (2005) Does stream morphology predict the home range size in burbot? Environ Biol Fishes 74:89-98

Slavík O, Horký P, Bartoš L, Kolářová J, Randák T (2007) Diurnal and seasonal behaviour of adult and juvenile European catfish as determined by radio-telemetry in the River Berounka, Czech Republic. J Fish Biol 71: 101-114
Slavík O, Pešta M, Horký P (2011) Effect of grading on energy consumption in European catfish Silurus glanis. Aquaculture 313:73-78

* Slavík O, Horký P, Randák T, Balvín P, Bílý M (2012) Brown trout spawning migration in fragmented central European headwaters: effect of isolation by artificial obstacles and the moon phase. Trans Am Fish Soc 141: $673-680$

* Slavík O, Horký P, Závorka L (2014) Energy cost of European catfish space use as determined by biotelemetry. PLOS ONE 9:e98997

* Slavík O, Horký P, Douda K, Velíšek J, Kolářová J, Lepič P (2017) Parasite-induced increases in the energy costs of movement of host freshwater fish. Physiol Behav 171: $127-134$

Slavík O, Horký P, Maciak M, Horká P, Langrová I (2018) Diel movement of brown trout, Salmo trutta, is reduced in dense populations with high site fidelity. Ecol Evol 8: 4495-4507

* Stapanian MA, Madenjian CP, Witzel LD (2006) Evidence that sea lamprey control led to recovery of the burbot population in Lake Erie. Trans Am Fish Soc 135: 1033-1043

Stapanian MA, Paragamian VL, Madenjian CP, Jackson JR, Lappalainen J, Evenson MJ, Neufeld MD (2010) Worldwide status of burbot and conservation measures. Fish Fish 11:34-56

Sundström LF, Lõhmus M, Johnsson IJ (2003) Investment in territorial defense depends on rearing environment in brown trout (Salmo trutta). Behav Ecol Sociobiol 54: 249-255

* Thorstad EB, Heggberget TG, Økland F (1998) Migratory behaviour of adult wild and escaped farmed Atlantic salmon, Salmo salar L., before, during and after spawning in a Norwegian river. Aquacult Res 29:419-428

Trabelsi A, Gardeur JN, Teletchea F, Fontaine P (2011) Effects of 12 factors on burbot Lota lota (L., 1758) weaning performances using fractional factorial design experiment. Aquaculture 316:104-110

Kuglem I, Bjørn PA, Dale T, Kerwath S and others (2008) Movements and spatiotemporal distribution of escaped farmed and local wild Atlantic cod (Gadus morhua L.). Aquacult Res 39:158-170

Weatherley AH, Kaseloo PA, Gare MD, Gunn JM, Lipicnik B (1996) Field activity of lake trout during the reproductive period monitored by electromyogram radiotelemetry. J Fish Biol 48:675-685

*Weir LK, Hutchings JA, Fleming IA, Einum S (2004) Dominance relationships and behavioural correlates of individual spawning success in farmed and wild male Atlantic salmon, Salmo salar. J Anim Ecol 73:1069-1079

White GC, Garrott RA (1990) Analysis of wildlife radiotracking data. Academic Press, San Diego, CA

*Wocher H, Harsányi A, Schwarz FJ (2011) Husbandry conditions in burbot (Lota lota L.): impact of shelter availability and stocking density on growth and behaviour. Aquaculture 315:340-347

Wringe BF, Fleming IA, Purchase CF (2015) Spawning success of cultured and wild male Atlantic cod Gadus morhua does not differ during paired contests. Mar Ecol Prog Ser 535:197-211

Zimmermann EW, Purchase CF, Fleming IA, Brattey J (2013) Dispersal of wild and escapee farmed Atlantic cod (Gadus morhua) in Newfoundland. Can J Fish Aquat Sci 70:747-755

Submitted: March 29, 2020

Accepted: December 3, 2020

Proofs received from author(s): February 23, 2021
St. John's, Newfoundland and Labrador, Canada

Reviewed by: 4 anonymous referees 